\title{
Dynamics and Distribution of Nutrients during the Development of Plantlets of Habanero Pepper
}

\author{
Manuel Martínez-Estévez, ${ }^{1}$ Nancy Ruiz-Lau, ${ }^{2}$ Rita Elena May-Uluac, ${ }^{2}$ \\ Adolfo Guzmán-Antonio, Fausto Quintal-Tun, and \\ Ramón Pacheco-Arjona \\ Unidad de Bioquímicay Biología Molecular de Plantas, Centro de Investigación \\ Cientifica de Yucatán, Mérida, Yucatán, México 97200
}

Additional index words. nutrients, habanero pepper, plantlets

\begin{abstract}
Dynamics and distribution of $\mathrm{K}, \mathrm{Ca}, \mathrm{Mg}, \mathrm{P}$, and $\mathrm{Na}$ were studied in leaves of three cultivars of habanero pepper (Capsicum chinense Jacq.) at the time of transplanting and 8 and 14 weeks afterward. Most nutrients analyzed were mobilized from younger to mature leaves, except for $P$, which occurred in the opposite direction, probably due to its role in the synthesis of nucleic acids, which is more active in young tissues. Information about mineral distribution in leaves during the first 14 weeks after transplantation could be used to indicate plant nutritional status and fertilizer requirements.
\end{abstract}

Peppers (Capsicum spp.) are agricultural products of great demand in international markets, either as fresh or dried fruit, or as an industrial supply to obtain a variety of end-products. Habanero pepper has acquired considerable importance due to its great genetic diversity and the high pungency of its fruit. As in other peppers, pungency in the habanero depends on environmental factors, including soil properties such as texture, osmotic properties, and nutrient availability, which had been poorly studied (Soria-Fregoso et al., 2002).

Nutrient mobilization rates have been calculated for many species of conifers and for an extensive group of perennial trees (Chapin and Kedrowski, 1983; Helmisaari, 1992; Killingbeck, 1996; Loneragan, 1997; Nambir and Fife, 1987; Wendler etal., 1995). Nevertheless, there is insufficient comparable data for the Capsicum genus. There are just two reports on mineral supplementation in Capsicum annun-one on improving Jalapeño pungency level, plant growth, and pot yield (Johnson and Decoteau, 1996) and the other on studying the effects of fertilizer supplementation on fruit development and pungency in Padron peppers (Estrada et al., 1998) - and only one on $C$. annum in which the authors reported that sweet pepper possesses characteristics for well-controlled recirculation of sodium (Blom-Zandstra et al., 1998).

Local agricultural manuals recommend

Received for publication 11 Oct. 2005. Accepted for publication 10 Dec. 2005. This research has been supported by a grant of Fundación Produce Yucatán (project 0510). We are grateful to Sergio R. Peraza Sánchez for the translation of this manuscript and Felipe Vazquez Flota and three anonymous reviewers provided helpful comments on an earlier version of the manuscript, also we are grateful to Ing. Eliazar Xool to provide the habanero pepper plants. Dedicated to the loving memory of my little princess Taty and to my dear friend José Armando Escamilla-Bencomo.

${ }^{1}$ Corresponding author; e-mail luismanh@cicy.mx. ${ }^{2}$ Both authors contributed equally to this work. using 125,100 , and $150 \mathrm{~kg} \cdot \mathrm{ha}^{-1}$ of $\mathrm{N}, \mathrm{P}$, and $\mathrm{K}$, respectively, to get maximum yields (SoriaFregoso et al., 2002); however, there is little information about the nutrimental plant status at the time of fertilization. Nutrient level in leaves, expressed as quantity per foliar area, has a considerable ecological and agricultural importance since it represents an index of the cost of construction of the photosynthetic surface (Medina, 1984).

The purpose of this work is to analyze the nutritional condition in leaves, in terms of the quantitative presence of $\mathrm{Ca}, \mathrm{Mg}, \mathrm{K}, \mathrm{P}$, and $\mathrm{Na}$, which play a major role in plant development and function. The information can be used as an important tool to diagnose possible nutritional disorders of plants of habanero pepper.

\section{Materials and Methods}

Plant materials and conditions. Threeweek-old habanero pepper plants of the local variety of orange fruit were obtained in Chicxulub, Yucatán, México (latitude $21^{\circ} 0.1$ $\mathrm{N}$ longitude $\left.89^{\circ} 34 \mathrm{~W}\right)$. Plants were germinated from seeds in Pet Moss (Cosmo Peat, Cosmocell distributor) until they reached 12 to $15 \mathrm{~cm}$ in height and presented five pair of leaves before be transplanted to plastic bags containing $500 \mathrm{~g}$ of a mixture of 2 red soil (luvisol) : 1 sand (by volume). Three sets of plants were organized. The first one consisted offive individual plants harvested 3 weeks after germination, before transplanting, whereas

Table 1. Concentration of the different elements studied in the youngest (top pair of leaves) and the oldest (bottom pair of leaves) leaves given in $\mathrm{g} \cdot \mathrm{kg}^{-1}$ (dry weight). ${ }^{1}$

\begin{tabular}{|c|c|c|c|c|c|c|}
\hline \multirow[b]{2}{*}{ Element } & \multicolumn{2}{|c|}{$\begin{array}{l}\text { Harvest } 1 \\
(3 \text { weeks) }\end{array}$} & \multicolumn{2}{|c|}{$\begin{array}{l}\text { Harvest } 2 \\
(8 \text { weeks) }\end{array}$} & \multicolumn{2}{|c|}{$\begin{array}{c}\text { Harvest } 3 \\
\text { (14 weeks) }\end{array}$} \\
\hline & First leaf & Last leaf & First leaf & Last leaf & First leaf & Last leaf \\
\hline $\mathrm{K}$ & $33.84 \pm 2.2$ & $55.03 \pm 2.5$ & $27.92 \pm 2.5$ & $43.66 \pm 5.8$ & $27.96 \pm 2.5$ & $33.76 \pm 5.8$ \\
\hline $\mathrm{Ca}$ & $13.49 \pm 1.5$ & $33.40 \pm 1.7$ & $37.78 \pm 4.0$ & $51.39 \pm 4.2$ & $13.12 \pm 3.7$ & $41.33 \pm 6.1$ \\
\hline $\mathrm{Mg}$ & $48.46 \pm 5.2$ & $148.37 \pm 6$ & $7.45 \pm 1.3$ & $18.11 \pm 3.1$ & $4.21 \pm 2.6$ & $14.12 \pm 6$ \\
\hline $\mathrm{Na}$ & $0.83 \pm 0.12$ & $0.16 \pm 0.13$ & $4.49 \pm 2.2$ & $6.2 \pm 2.3$ & $7.64 \pm 2.4$ & $6.36 \pm 5.5$ \\
\hline $\mathrm{P}$ & $35.13 \pm 6.2$ & $4.59 \pm 1.03$ & $9.81 \pm 1.03$ & $2.07 \pm 0.23$ & $5.9 \pm 0.47$ & $1.70 \pm 0.08$ \\
\hline
\end{tabular}

zTukey's multiple test $(p \leq 0.05)$ performed with the StatGraphics v. 5.1 program. the second and third sets (of five plants each) were allowed to develop for 8 and 14 weeks, respectively.

Sample harvest and processing. In each sampling, all leaves of each plant were harvested, sorted out by size, and wrapped in aluminum foil. Leaves were numbered, starting with the youngest one. Leaves were weighed and dried individually in an oven to a constant weight at $60^{\circ} \mathrm{C}$ for $48 \mathrm{~h}$. Porcelain crucibles containing leaf samples were placed in a oven, muffle furnace type, at $200^{\circ} \mathrm{C}$ for $1 \mathrm{~h}$ and then at $500{ }^{\circ} \mathrm{C}$ for $2 \mathrm{~h}$. The ashes obtained were digested with $5 \mathrm{~mL}$ of $40 \% \mathrm{HCl}$ and the slurry was evaporated to dryness on a hot plate. The residue was dissolved in $1 \mathrm{~mL}$ of concentrated $\mathrm{HCl}$ and placed in test tubes, where $9 \mathrm{~mL}$ of distilled water was added.

Determination of $\mathrm{Ca}, \mathrm{Mg}, \mathrm{K}$, and $\mathrm{Na}$. These determinations were performed using a atomic absorption spectrophotometer (model 3100; Perkin Elmer) operated at wavelengths of 400 to $766 \mathrm{~nm}$ with a detection range of 0 to $5.0 \mathrm{mg} \cdot \mathrm{L}^{-1}$, depending on the analyzed ion, according to Greenberg et al. (1992). PE Pure atomic spectrophotometer standards were used in the measure of the nutrients.

Determination of $P$. Phosphorous was colorimetrically analyzed with ascorbic acid as described by Murphy and Riley (1962). Readings of the blue complex formed were taken on a spectrophotometer (DU 65; Beckman) at $880 \mathrm{~nm}$, with a detection range of $0.04 \mathrm{mg} \cdot \mathrm{L}^{-1}$

Statistic analysis. Data were submitted to analysis of variance and Tukey's multiple media test $(p \leq 0.05)$ using the StatGraphics v. 5.1 package. All data were recorded as the average of three independent experiments.

\section{Results and Discussion}

Habanero pepper plants that were 3 weeks old at the time of transplantation were cultivated in a mix of 2 soil : 1 sand with the following concentrations of mineral nutrients (all dry weight): $\mathrm{K}=0.002275 \pm 00052 \mathrm{~g} \cdot \mathrm{kg}^{-1}$, $\mathrm{Ca}=0.2062 \pm 0.0054 \mathrm{~g} \cdot \mathrm{kg}^{-1}, \mathrm{Mg}=0.01246 \pm$ $0.00079 \mathrm{~g} \cdot \mathrm{kg}^{-1}, \mathrm{Na}=0.014 \pm 0.00084 \mathrm{~g} \cdot \mathrm{kg}^{-1}$, and $\mathrm{P}=2.83 \times 10^{-5} \pm 10^{-5} \mathrm{~g} \cdot \mathrm{kg}^{-1}$.

These plants, for which the mineral contents are shown in Table 1, had been maintained inside the greenhouse and were in good physiological conditions with five pairs of leaves. Figure 1 shows the concentration of the studied ions, expressed in $\mathrm{g} \cdot \mathrm{kg}^{-1}$ of dry weight. In 3week-old plants, the concentrations of $\mathrm{K}, \mathrm{Ca}$, and $\mathrm{Mg}$ ions increased from the younger, upper leaves to the older ones, located in the lower 
stem positions. This trend was similar in 8 - and 14-week-old plants (Fig. 1A-C). Differences in ion concentrations were more pronounced among the top and bottom pairs of leaves in 3 -week-old plants than in the older ones. This was more evident for $\mathrm{K}$ and $\mathrm{Mg}$ than for $\mathrm{Ca}$ (Fig. 1A and C).

To compensate the effect of leaf expansion and biomass accumulation, data were recalculated as total ion content per leaf (Fig. 2), both for $\mathrm{K}$ (33.84 to $55.03 \mathrm{~g} \cdot \mathrm{kg}^{-1}$ ) and $\mathrm{Mg}$ (48.46 to $148.37 \mathrm{~g} \cdot \mathrm{kg}^{-1}$ ) (Fig. 2B and C, Table 1).

The mobilization of these ions is an expected response, since the plant accumulates $\mathrm{Mg}$ through the synthesis of chlorophylls. In the case of $\mathrm{K}$, the mobilization is directly related to the functionality of the stoma as well as of the other multiple functions with which $\mathrm{K}$ is involved. Similar results have been reported for Phoenix canariensis (Broschat, 1997).

In habanero pepper there do not exist any reports, not even about the role of $\mathrm{K}$ fertility as it affects pepper plant growth yield and pungency. There are two reports on Capsicum annun L. and the relationship of the effects of the mineral supplementation on fruit development and pungency. Biomass, fruit count, and fruit weight per plant increased linearly with increasing $\mathrm{K}$ rate (Johnson and Decoteau, 1996). Fertilization regime may alter the balance of the competition between capsaicinoid biosynthesis and accumulation of lignin-like substances in the cell wall (Estrada, et al., 1998), but nothing has been reported in relation to measure of the nutritional conditions of chilli pepper plants.

For plants belonging to the Solanaceae family, $\mathrm{Na}$ is not an essential nutriment and it could even be the cause of damage (Adams et al., 1995). The concentration of Na decreased in the leaves of plants harvested at 3 weeks but increased slowly in the leaves of plants harvested at 8 and 13 weeks. Blom Zandstra et al. (1998) reported that, in sweet pepper ( $C$. annun), pith cells, the intermediates between the xylem and phloem, play a decisive role in the recirculation of $\mathrm{Na}$ throughout the plant. This study was done under hydroponic conditions and found that sweet pepper possesses the same characteristics for well-controlled recirculation of $\mathrm{Na}$ as described for bean (Jacoby, 1979)

The mobilization of nutrients from young to well developed leaves has been reported for conifers, in which it was noticed that mobilization is independent of leaf senescence (Escudero et al., 1992; Nambiar and Fife, 1987). For Na and P (Fig. 1D and E), youngest leaves had greater quantities of these ions, and significant differences were found between the first and the last leaves (Table 1); thus, we conclude that the mobilization of these two elements is carried out from the oldest to the youngest leaves.

The tendency observed, as in the case of the other two ions described previously, is that the ions are mobilized from the oldest to the youngest leaves, although we need to highlight that the detected quantities were low, which could be due to the direct involvement of $\mathrm{Na}$ in maintaining the osmotic potential of grow- ing leaves. The concentration of $\mathrm{Ca}$ increases consistently as the leaf ages (Fig. 1B, Table 1). The totally expanded young leaves could be a good indicator of the status of Ca in this species. Prevot and Monbreton (1958) have shown a similar increment in the concentration of $\mathrm{Ca}$ along with leaf senescence in African palms, but Amalu et al. (1988) have reported a slight decrease in Ca concentration in 'Nigerian Tall' coconut palms while the plants age.

In all the cases (Fig. 1A-D), except for $\mathrm{P}$ (Fig. 1E), during the second and third harvests ( 8 and 14 weeks after transplantation), the tendency of the ions studied is to be mobilized from the youngest to the oldest leaves with the purpose of being eliminated, since in high

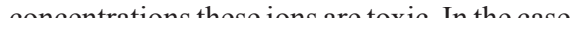

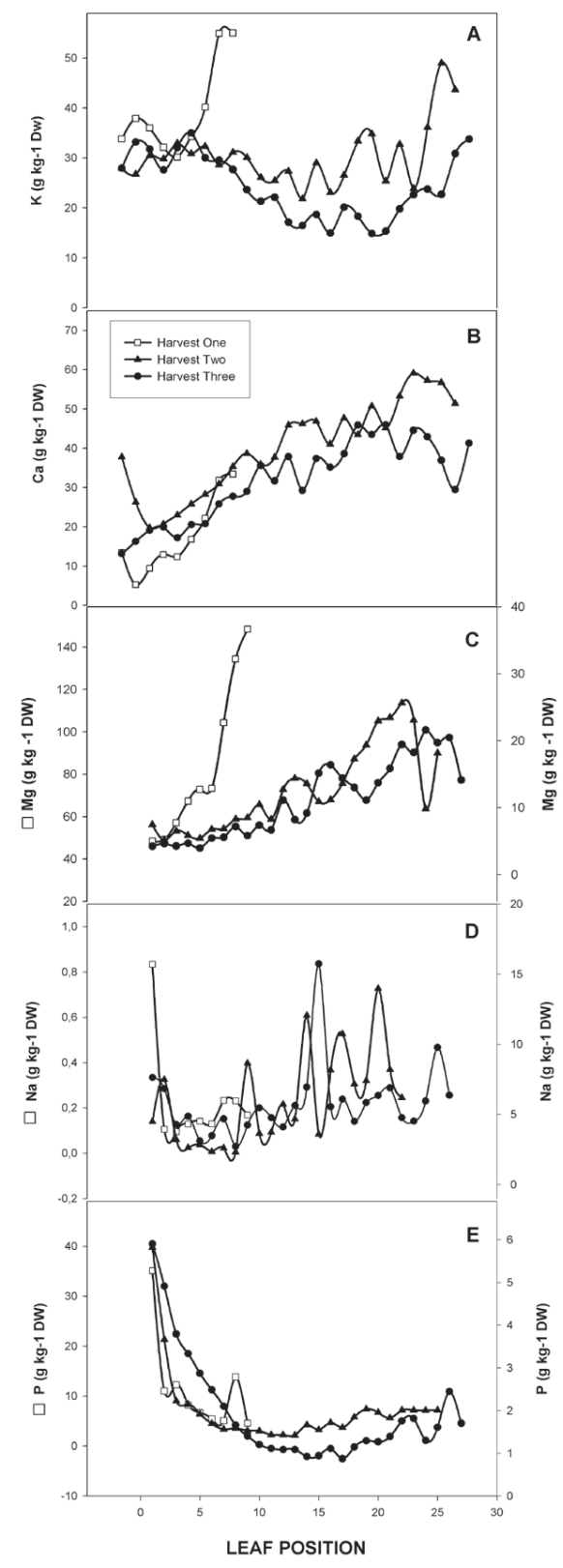

Fig. 1. Concentration of $\mathrm{K}(\mathbf{A}), \mathrm{Ca}(\mathbf{B}), \mathrm{Mg}(\mathbf{C})$, $\mathrm{Na}(\mathbf{D})$, and $\mathrm{P}(\mathbf{E})$, as $\mathrm{g} \cdot \mathrm{kg}^{-1}$ dry weight (DW), in leaves of Capsicum chinense plants 3 (D), $8(\boldsymbol{\Delta})$, or $13(\bullet)$ weeks old. Leaf in position 1 represents the youngest fully expanded pair of leaves, located in the upper stem. Average of three independent repetitions. of $\mathrm{P}$, the tendency was to keep its mobilization from the oldest to the youngest leaves (Table 1 ), due to its role in the synthesis of nucleic acids as well as the part it plays in transferring energy needed for the phosphorylation of proteins used for cell growth and cellular differentiation (Budded and Chollet, 1988).

Figure 2 represents the total quantity of the different nutrients present in the leaves of habanero pepper plants. The tendency of the three crops is the same: there was an increase of the nutrient quantities in leaf four (Fig. 2A-E), which is indicated by the increment of leaf growth, which occurs along with a total increment of the studied nutrients. It was noticed that the quantities of the nutrients began to diminish from leaf five to the last one in all the crops studied, indicating that there is a mobilization of nutrients toward the intermediate leaves;

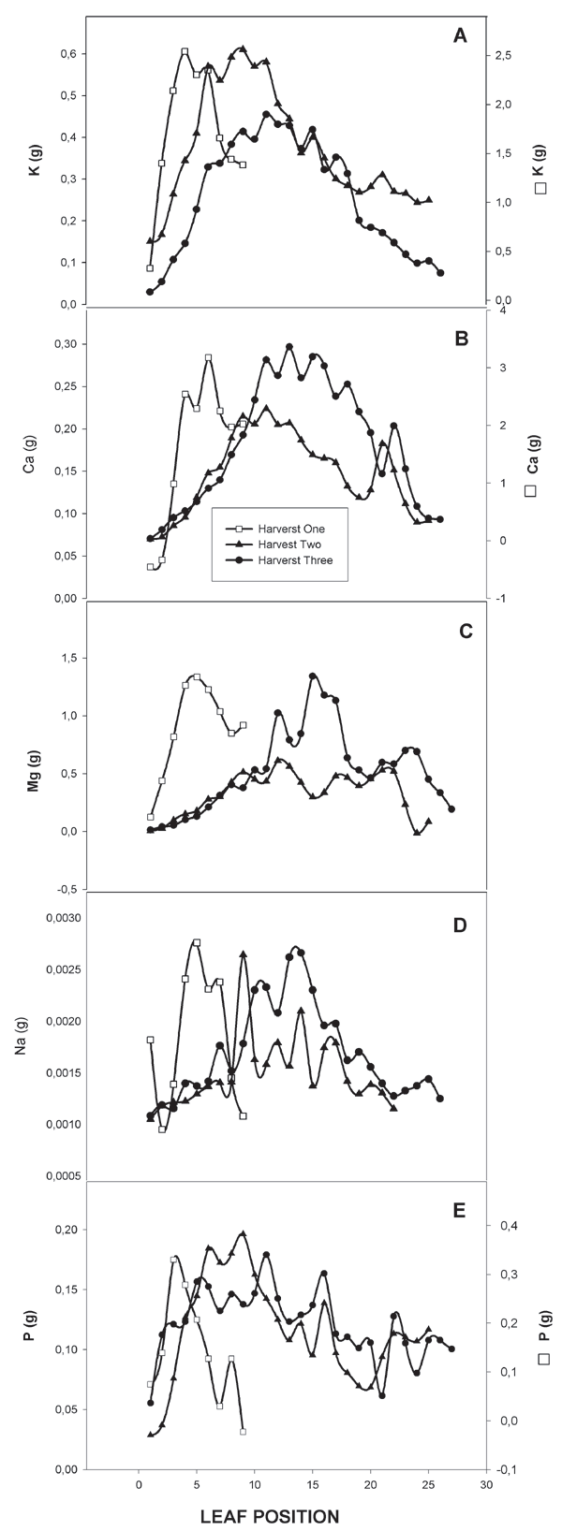

Fig. 2. Total content of $\mathrm{K}(\mathbf{A}), \mathrm{Ca}(\mathbf{B}), \mathrm{Mg}(\mathbf{C}), \mathrm{Na}$ (D), and $\mathbf{P}(\mathbf{E})$, in leaves of Capsicum chinense plants $3(\square), 8(\boldsymbol{\Delta})$, or $13(\boldsymbol{\nabla})$ weeks old. Leaf in position 1 represents the youngest fully expanded pair of leaves, located in the upper stem. Average of three independent repetitions. 
these are the leaves with highest metabolism that require all these nutrients for adequate development. Although the youngest leaves continue gaining fresh weight, the quantity or the accumulation of these nutrients does not vary due to the mobilization phenomenon. Similar results have been observed in senescent leaves of 89 species of deciduous and evergreen woody perennials (Killingbeck, 1996).

\section{Conclusions}

Never before have chilli pepper plants been studied in relation to their nutritional conditions. Only the role of N, P, and K fertility on Jalapeño and Padrón pepper plant growth, yield, and pungency have been reported. This is the first report on the dynamics and distribution of nutrients in plants of habanero pepper. The nutrients studied seem to be highly mobile in the leaves of habanero pepper plants. The mobility of $\mathrm{Ca}$, $\mathrm{K}$, and $\mathrm{Mg}$ increases with leaf age, while that of $\mathrm{P}$ decreases. In the case of $\mathrm{Na}$, no difference was observed in the leaves studied, suggesting that habanero pepper plants do not accumulate this element. The studies carried out in this work can serve as a measure of the nutritional conditions of habanero pepper plants.

\section{Literature Cited}

Adams, P., L.C. Ho, R. Fernandez-Muñoz, J. Cuartero, and M.L. Gomez-Guilamon. 1995. Uptake and distribution of nutrients in relation to tomato fruit quality. Acta Hort. 412:374-387.

Amalu, U.C., D.O. Ataga and U. Omoti. 1988 The distribution of nutrient elements in leaves of Nigerian Tall coconuts. Niger. J. Palms Oil Seeds 9:2-15.

Broschat, T.K. 1997 Nutrient distribution, dynamic, and sampling in coconut and Canary Island palms. J. Amer. Soc. Hort. Sci. 122:884-890.

Budded, R.J.A. and R. Chollet 1988. Regulation of enzyme activity in plants by reversible phosphorylation. Physiol. Plant. 72:435-439.

Blom-Zandstra, M., S.A. Vogelzang, and B.W. Veen 1998. Sodium fluxes in sweet pepper exposed to varying sodium concentrations. J. Expt. Bot. 328:1863-1868.

Chapin, III, F.S. and R. A. Kedrowski. 1983. Seasonal changes in nitrogen and phosphorus fraction and autumn retranslocation in evergreen and deciduous taiga trees. Ecology 64:376-391.

Escudero, A., J.M. del Arco, I.C. Sanz, and J. Ayala. 1992 Effects of leaf longevity and retranslocation efficiency on the retention time of nutrients in the leaf biomass of different woody species. Oecologia 90:80-87.

Estrada, B., F. Pomar J. Diaz, F. Merino, and M.A. Bernal(1998) Effects of mineral fertilizer supplementation on fruit development and pungency in Padron peppers. J. Hort. Sci. Biotechnol. 73:493-497.

Greenberg, A.E., L.S. Clesceri, and A.D. Eaton. 1992. Standard methods for the examination of water and wastewater. Amer. Public Health Assn., Wash., D.C.

Helmisaari, H.S. 1992. Nutrient retranslocation in three Pinus sylvestris stands. For. Ecol. Mgt. 51:347-367

Jacoby, B. 1979. Sodium recirculation and loss from
Phaseolus vulgaris L. Ann. Bot. 43:741-744

Johnson, C.D. and D.R. Decoteau 1996. Nitrogen and potassium fertility affects jalapeño pepper plant growth, pt yield and pungency. HortSience 31:1119-1123.

Killingbeck, K.T. 1996. Nutrient in senescence leaves: Keys to the search for potential resorption and resorption proficiency. Ecology 77:1716-1727.

Loneragan, J.F. 1997 Plant nutrition in the 20th and perspectives for the 21 st century. Plant Soil 196:163-174

Medina, E, 1984. Nutrient Balance and Physiological processes at the leaf level, p. 139-154. In: E.H. Medina, A. Money, and C. Vazquez-Yanes (eds.). Physiological ecology of plant of the wet tropics. Junk Publ., Hague, The Netherlands.

Murphy, A. and P. Riley 1962. A modified single solution for determination of phosphate in natural waters. Anal. Chem. Acta. 27:31-36

Nambiar, E.K.S. and D.N. Fife 1987 Growth and nutrient retranslocation in needles of radiate pine in relation to nitrogen supply. Ann. Bot. 60:147-156

Prevot, P. and C.P. Montbreton 1958. Etude des gradients en divers éléments mineraux selon le rang de la feulle chez le palmier a huile. Oleagineux 13:317-321

Soria-Fregoso, M.J., J.A. Trejo Rivero, J.M. Tun Suarez, and R. Teran-Saldivar. 2002. Paquete tecnologico para la producción de chile habanero (Capsicum chinense Jack), no. 2, p. 3-74. Educ. Inst. Tecnologico de Merida.

Wendler, R., P.O. Carvalho, J.S. Pereira, and P. Millard. 1995. Role of nitrogen remobilization from old leaves for new leaf growth of Eucalyptus globules seedlings. Tree Physiol. 15:679-683. 